\title{
Reoperation for growth hormone-secreting pituitary adenomas: report on an endonasal endoscopic series with a systematic review and meta-analysis of the literature
}

\author{
João Paulo Almeida, MD, Armando S. Ruiz-Treviño, MD, Buqing Liang, MD, Sacit B. Omay, MD, \\ Sathwik R. Shetty, MBBS, DNB (Neurosurgery), Yu-Ning Chen, MD, Vijay K. Anand, MD, \\ Kartikey Grover, MS, Paul Christos, DrPH, and Theodore H. Schwartz, MD
}

Department of Neurosurgery, Weill Cornell Medical College, NewYork-Presbyterian Hospital, New York, New York

\begin{abstract}
OBJECTIVE Surgery is generally the first-line therapy for acromegaly. For patients with residual or recurrent tumors, several treatment options exist, including repeat surgery, medical therapy, and radiation. Reoperation for recurrent acromegaly has been associated with poor results, with hormonal control usually achieved in fewer than $50 \%$ of cases. Extended endonasal endoscopic approaches (EEAs) may potentially improve the results of reoperation for acromegaly by providing increased visibility and maneuverability in parasellar areas.
\end{abstract}

METHODS A database of all patients treated in the authors' center between July 2004 and February 2016 was reviewed. Cases involving patients with acromegaly secondary to growth hormone $(\mathrm{GH})$-secreting adenomas who underwent EEA were selected for chart review and divided into 2 groups: first-time surgery and reoperation. Disease control was defined by 2010 guidelines. Clinical and radiological characteristics and outcome data were extracted. A systematic review was done through a MEDLINE database search (2000-2016) to identify studies on the surgical treatment of acromegaly. Using PRISMA (Preferred Reporting Items for Systematic Reviews and Meta-Analyses) guidelines, the included studies were reviewed for surgical approach, tumor size, cavernous sinus invasion, disease control, and complications. Cases were divided into reoperation or first-time surgery for comparative analysis.

RESULTS A total of 44 patients from the authors' institution were included in this study. Of these patients, 2 underwent both first-time surgery and reoperation during the study period and were therefore included in both groups. Thus data from 46 surgical cases were analyzed (35 first-time operations and 11 reoperations). The mean length of follow-up was 70 months (range 6-150 months). The mean size of the reoperated tumors was $14.8 \pm 10.0 \mathrm{~mm}$ ( 5 micro- and 6 macroadenomas). The patients' mean age at the time of surgery was younger in the reoperation group than in the first-time surgery group ( $34.3 \pm 12.8$ years vs $49.1 \pm 15.7$ years, $p=0.007$ ) and the mean preoperative GH level was also lower $(7.7 \pm 13.1 \mu \mathrm{g} / \mathrm{L}$ vs $25.6 \pm 36.8 \mu \mathrm{g} / \mathrm{L}, p=0.04)$. There was no statistically significant difference in disease control rates between the reoperation $(7[63.6 \%]$ of 11$)$ and first-time surgery $(25[71.4 \%]$ of 33$)$ groups $(p=0.71)$. Univariate analysis showed that older age, smaller tumor size, lower preoperative GH level, lower preoperative IGF-I level, and absence of cavernous sinus invasion were associated with higher chances of disease control in the first-time surgery group, whereas only absence of cavernous sinus invasion was associated with disease control in the reoperation group $(p=$ 0.01). There was 1 case (9\%) of transient diabetes insipidus and hypogonadism and $1(9 \%)$ postoperative nasal infection after reoperation. The systematic review retrieved 29 papers with 161 reoperation and 2189 first-time surgery cases. Overall disease control for reoperation was $46.8 \%(95 \% \mathrm{Cl} 20 \%-74 \%)$ versus $56.4 \%(95 \% \mathrm{Cl} 49 \%-63 \%)$ for first-time operation. Reoperation and first-time surgery had similar control rates for microadenomas $(73.6 \%$ [ $95 \% \mathrm{Cl} 32 \%-98 \%]$ vs $77.6 \%[95 \% \mathrm{Cl} 68 \%-85 \%]$ ); however, reoperation was associated with substantially lower control rates for macroadenomas $(27.5 \%$ [ $95 \% \mathrm{Cl} 5 \%-57 \%]$ vs $54.3 \%[95 \% \mathrm{Cl} 45 \%-62 \%])$ and tumors invading the cavernous sinus $(14.7 \%[95 \% \mathrm{Cl}$ $4 \%-29 \%]$ vs $38.5 \%[95 \% \mathrm{Cl} 27 \%-50 \%])$.

CONCLUSIONS Reoperative EEA for acromegaly had results similar to those for first-time surgery and rates of control

ABBREVIATIONS DI = diabetes insipidus; EEA = endoscopic endonasal approach; GH = growth hormone; IGF-I = insulin-like growth factor-I; PRISMA = Preferred Reporting Items for Systematic Reviews and Meta-Analyses; PRL = prolactin.

SUBMITTED October 21, 2016. ACCEPTED February 9, 2017.

INCLUDE WHEN CITING Published online September 1, 2017; DOI: 10.3171/2017.2.JNS162673. 
for macroadenomas that were better than historical rates. Cavernous sinus invasion continues to be a negative prognostic indicator for disease control; however, results with EEA show improvement compared with results reported in the prior literature.

https://thejns.org/doi/abs/10.3171/2017.2.JNS162673

KEY WORDS acromegaly; endoscopic; endonasal; growth hormone; pituitary tumor; reoperation; transsphenoidal; pituitary surgery

$\mathrm{E}$ FFECTIVE treatment of growth hormone (GH)-secreting pituitary adenomas should achieve normalization of excessive $\mathrm{GH}$ and insulin-like growth factor-I (IGF-I) secretion and alleviation of pituitary mass effect while preserving the other pituitary functions. ${ }^{12,30,32,43}$ A multidisciplinary approach is recommended to achieve those goals, with collaboration among neurosurgeons, endocrinologists, and radiation oncologists. Surgical treatment remains the gold standard treatment unless specifically contraindicated. ${ }^{32}$ An aggressive operative management to lower serum GH levels is recommended once the diagnosis has been confirmed. Transsphenoidal surgery is the main surgical approach for resection of GH-secreting adenomas, promoting hormonal control in $38 \%-83 \%$ of patients..$^{26,29,41,56,63}$ In the last 15 years, the endoscopic endonasal approach (EEA) has proven to be an important option for the treatment of those lesions. ${ }^{6-8,15,28,56}$ EEA provides some advantages over more traditional transsphenoidal microscope-based approaches, including improved surgical visualization, less nasal trauma, increased patient comfort, and potentially better results with respect to total tumor resection. . $^{27,28,56}$

Although surgery can lead to biochemical remission in a large portion of patients, almost one-third of GHsecreting tumors may not be cured after initial surgery. ${ }^{31}$ Treatment options for those cases include medical therapy, radiation therapy, and reoperation..$^{32,42,44}$ Somatostatin receptor ligands (octreotide, lanreotide), dopamine agonists (cabergoline), and pegvisomant, a human GH receptor antagonist, are important tools in the management of acromegaly, but the costs of treatment, lifelong therapy, and the occurrence, in some cases, of major side effects represent important limitations of medical therapy.,3,24 Stereotactic radiotherapy plays a role in the treatment of residual tumors after resective surgery, particularly if medical therapy is not available or successful. Although radiosurgery has been associated with disease control in approximately $45 \%$ of patients, ${ }^{65}$ it usually takes years to achieve its full effect and this treatment may be associated with visual deficits and hypopituitarism..$^{24,32,43,65}$

Reoperation for persistent acromegaly is recommended when residual intrasellar tumor is observed and/or adjuvant therapy is not effective or cannot be performed due to a patient's economic limitations. ${ }^{32,42}$ Hormonal control rates after repeat surgery have been historically inferior to those achieved after initial surgery.,42,64 However, we hypothesize that with the implementation of EEA, current results of reoperation for GH-secreting adenomas may be better than previously reported and may be similar to results of first-time surgery. In the current study we evaluated the results of EEA performed by a dedicated endoscopic skull base team for reoperation in patients with persistent acromegaly. In addition, we performed a systematic review of the literature focused on the results of reoperation for GH-secreting adenomas as a historical control for comparison.

\section{Methods}

\section{Study Design}

A prospectively acquired database of all cases involving patients treated at the Institute for Minimally Invasive Skull Base and Pituitary Surgery at Weill Cornell Medical College, NewYork-Presbyterian Hospital between July 2004 and February 2016 was reviewed, with institutional review board approval. Cases involving patients with acromegaly secondary to GH-secreting adenomas were selected for chart review. For analysis purposes, patients were included in 2 different groups: patients who underwent a first-time surgery and those who underwent reoperation. A team composed of specialists in neurosurgery, otolaryngology, endocrinology, ophthalmology, and radiation oncology was responsible for the care of all patients.

\section{Patient Population}

Patients with a clinical diagnosis compatible with acromegaly (GH > $1 \mu \mathrm{g} / \mathrm{L}$, IGF-I level greater than the normal age- and sex-adjusted level) who underwent EEA in our department and had a confirmed GH-secreting pituitary adenoma (confirmed as positive for GH marker through histological examination) with at least 6 months of followup were included in the study. Clinical data, including age, sex, previous treatments, pre- and postoperative hormonal status, complications, adjuvant therapies, duration of follow-up, and disease control, were collected through a retrospective chart review. Telephone calls were made to obtain up-to-date follow-up data for patients who did not have recent information in the chart. Patients treated with other surgical approaches and those with incomplete data were excluded from the study.

\section{Hormonal Assessment}

Preoperative and postoperative evaluations were performed for prolactin (PRL), free thyroxine, fasting morning cortisol, IGF-I, GH, testosterone, estrogen, folliclestimulating hormone (FSH), luteinizing hormone ( $\mathrm{LH})$, and serum sodium levels and urine specific gravity. The first postoperative hormonal evaluation was performed 24-48 hours after surgery and then a second was performed 3 months later. Follow-up endocrinological assessment was usually done every $6-12$ months, according to the referring endocrinologist and the clinical status of the patient. 


\section{Criteria for Disease Control}

As proposed by recent guidelines, ${ }^{23,32}$ criteria for disease control were normal IGF-I levels for age and sex and random GH level less than $1 \mu \mathrm{g} / \mathrm{L}$ or $\mathrm{GH}$ suppression after oral glucose tolerance test $(\mathrm{GH}<0.4 \mu \mathrm{g} / \mathrm{L})$. Initial evaluation of disease control was done 3 months after surgery and then every 6-12 months. Our goal was to attempt an oral glucose tolerance test to determine biochemical control in all patients, but this test is not always possible in patients referred by outside endocrinologists who may not comply or follow up reliably at our institution.

\section{Radiological Evaluation}

All patients underwent preoperative MRI. Tumors were analyzed using contrast-enhanced MR images on postoperative Day 1, at 3 months after surgery, and then at a yearly interval. Tumor size was classified according to maximum tumor diameter in 2 categories: microadenomas $(\leq 10 \mathrm{~mm})$ and macroadenomas $(>10 \mathrm{~mm})$. The Knosp classification ${ }^{46}$ was applied to evaluate the relation of the tumor with the cavernous sinus. Two of the authors (J.P.A. and A.S.R.T.) evaluated the images and had to agree about the tumor grading for final classification. Knosp Grades III and IV, i.e., those with three-fourths or more encasement of the internal carotid artery or crossing of the lateral intercarotid line by the tumor, were considered to present significant invasion of the cavernous sinus.

\section{Surgical Technique}

Following the induction of general anesthesia, antibiotics, glucocorticoids, and intrathecal fluorescein are given. ${ }^{51,59} \mathrm{~A}$ detailed description of the procedure has already been published..$^{39,53}$ Briefly, after topical exposure of the nasal mucosa to cocaine and injection of the mucosa of the middle turbinates with a mixture of lidocaine $1 \%$ and epinephrine $(1: 100,000)$, the sphenoid ostia are bilaterally identified and the bony opening is enlarged. In cases of large macroadenomas with suprasellar extension, a nasoseptal flap is harvested at the start of the case. The posterior third of the nasal septum adjacent to the vomer and maxillary crest is resected with a tissue shaver. The anterior wall of the sella is opened using a high-speed drill and curettes. Macroadenomas are first internally decompressed by removing the inferior and lateral portions of the tumor to prevent the suprasellar arachnoid from herniating down into the sella and obstructing the view. The suprasellar and parasellar components of the tumor are resected last. If necessary, extended approaches are performed to achieve maximal resection, such as transtuberculum transplanum approaches for large suprasellar lesions and transpterygoid approaches for adenomas with extension into the lateral compartment of the cavernous sinus. Angled endoscopes are used to enter the cavernous sinus and remove tumors in this region. Closure is performed in a multilayer fashion, as previously reported. ${ }^{50}$

\section{Statistical Analysis}

Statistical analysis was performed using SPSS (version 22.0, IBM Corp.). The Shapiro-Wilk test was applied for evaluation of a normal distribution of continuous vari- ables. These evaluation results are displayed as means with standard deviations and ranges. Values for categorical variables are shown as counts and percentages. Associations between the effects of tumor size, invasion of the cavernous sinus, and preoperative GH and IGF-I serum levels on endocrinological remission were calculated using a chi-square test for categorical variables and the Pearson correlation coefficient for continuous variables. Univariate analyses of nonparametric continuous variables across binary categories were compared using the Mann-Whitney U-test. Parametric continuous variables were compared using independent-sample t-tests. Proportions were compared using the chi-square or Fisher exact test, as appropriate. Two-sided significance tests were used throughout, and the significance level was kept at $\mathrm{p}<0.05$.

\section{Systematic Review of the Literature}

We performed a systematic review of the literature using the MEDLINE database through PubMed, from 2000 to 2016. The following terms were used for search: "acromegaly" AND "surgery," "acromegaly" AND "reoperation," "acromegaly" AND "persistent," "acromegaly" AND "recurrent," and "GH-secreting" AND "surgery." The search was limited to studies published in English, and humans were specified for the study category. The Preferred Reporting Items for Systematic Reviews and Meta-Analyses (PRISMA) guidelines ${ }^{40,47}$ were used (Fig. 1). Eligibility assessment was performed in an unblinded standardized manner by 2 reviewers (J.P.A. and A.S.R.T.). Manual search for manuscripts was also conducted by scrutinizing references from identified manuscripts, major neurosurgical journals and texts, and personal files. The date of the last search was August 2016. Disagreements between reviewers were resolved by consensus. Eligibility criteria included clinical series of patients treated surgically for acromegaly, through transsphenoidal microsurgical or endoscopic approaches, for first-time surgery or reoperation, which used the $2000^{22}$ or $2010^{23,32}$ guidelines for control of acromegaly. The decision to include papers that used either set of criteria was based on results of a pre-study that demonstrated that only 1 paper focused on reoperation used the 2010 criteria. The studies were divided into 2 groups, first-time surgery and reoperation studies. Editorials, commentaries, and review articles were not included, since they did not present original data. To avoid duplication of patients, in cases in which multiple papers were published from the same authors or same institution, only the report with the largest relevant cohort was included. Papers were excluded if they reported on a mixed population of reoperation and first-time surgery cases and did not present patient and outcome characteristics for each group.

Included studies were reviewed and carefully scrutinized by 2 researchers (A.S.R.T. and S.R.S.) for study design, methodology, patient characteristics, and primary findings. Patient data were extracted from the studies and used to categorize patients into cohorts according to tumor size (microadenomas or macroadenomas), cavernous sinus invasion, surgical approach (transsphenoidal microsurgery or EEA), and treatment type (first-time surgery or reoperation). The primary outcome was disease control obtained 


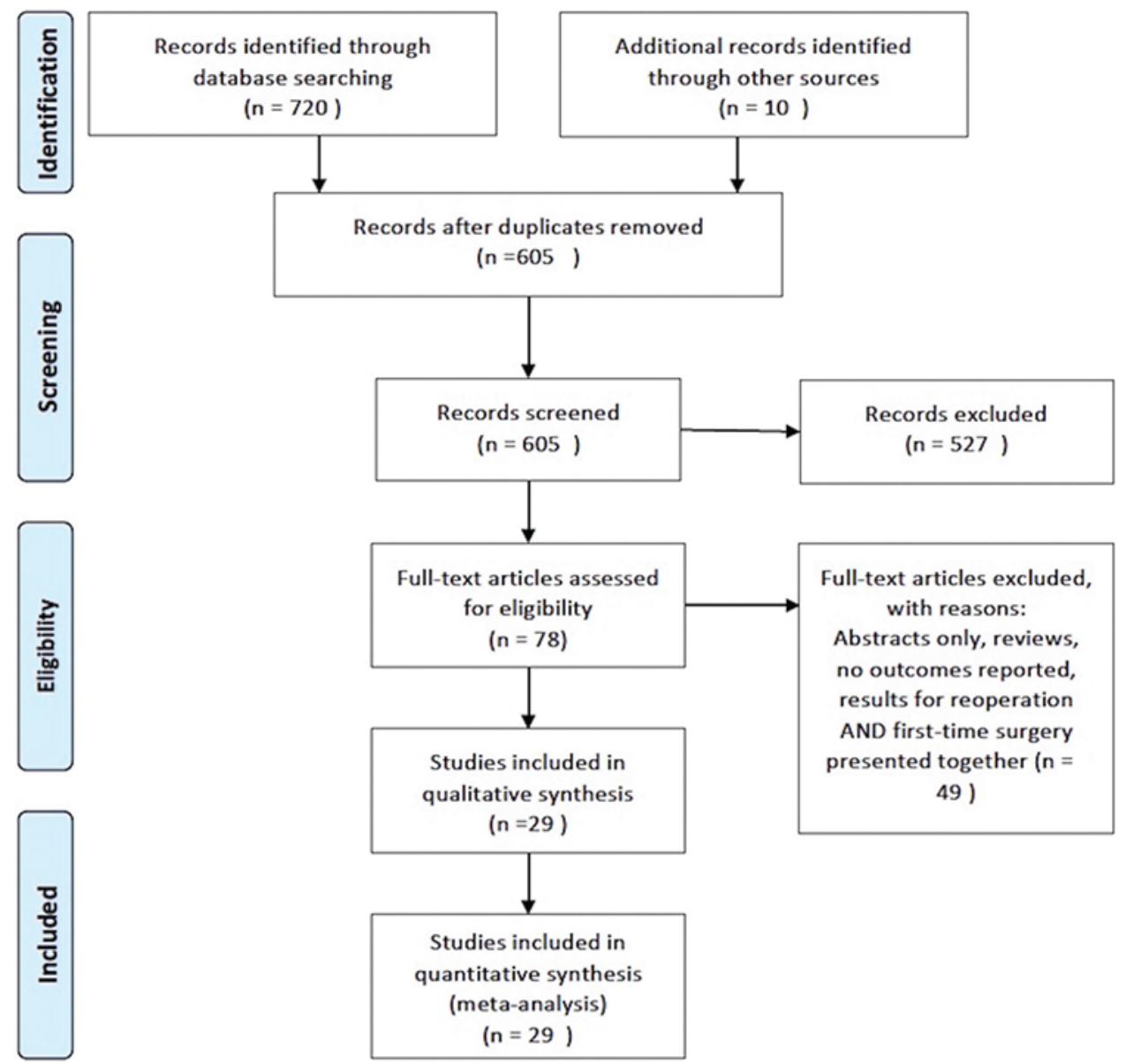

FIG. 1. PRISMA 2009 flow diagram for identification of papers included in the systematic review and meta-analysis. Modified with permission from Moher D, Liberati A, Tetzlaff J, Altman DG, The PRISMA Group (2009). Preferred Reporting Items for Systematic Reviews and Meta-Analyses: The PRISMA Statement. PLoS Med 6(7):e1000097. For more information, visit www.prismastatement.org. Figure is available in color online only.

with reoperation or first-time surgery, and secondary outcomes were disease control for each subgroup. Postoperative complications were recorded, including postoperative pituitary dysfunction, diabetes insipidus (DI), postoperative CSF leak, meningitis, cranial nerve palsies, carotid artery injuries, and rhinological complications.

Meta-analyses of the disease-control proportion for the overall reoperated and first-surgery groups, as well as for defined subgroups of interest (microadenomas, macroadenomas, cavernous sinus, microsurgery, and endoscopy), were conducted with the use of StatsDirect statistical software (version 3.0.181). Meta-analyses of specific complication proportions of interest (i.e., CSF leak, DI, hypopituitarism, rhinological complications, etc.) were also performed. Statistical heterogeneity was tested by use of the chi-square test (i.e., Cochran $\mathrm{Q}$ test), and a $\mathrm{p}$ value $\leq 0.20$ was used to indicate the presence of heterogeneity. In the case of a lack of heterogeneity, fixed-effects models were used for the meta-analyses. If heterogeneity was present $(p \leq 0.20)$ or a small number of studies were pooled, then random-effects models were used for the meta-analyses. For the disease-control proportion and complication proportions, the results of each study were expressed as binary proportions with exact $95 \%$ confidence intervals. The data collected through the systematic review represent a pool of clinical series, making our systematic review a synthesis of Level 3 evidence only.

\section{Results}

\section{Surgical Series}

Between 2004 and 2016, 47 patients with acromegaly underwent 49 endoscopic endonasal procedures performed by the senior surgeon authors (T.H.S. and V.K.A.). Three patients, who had each undergone a single operation, were excluded due to incomplete follow-up data, and the remaining 44 patients (46 procedures) were included in the study. The patients had a mean age of $45 \pm 16.2$ years (range 11-77 years) and a mean follow-up duration of 70 months (range 6-150 months). Patients who underwent EEA for reoperation for a GH-secreting adenoma represented 25\% (11 patients) of the overall studied cohort. Most of those patients (9 [81.2\%] of 11) had undergone a prior surgery in a different institution and had persistent acromegaly; 2 patients (18.2\%) had been previously treated via an EEA in our center. All patients in the reoperation group 
TABLE 1. Demographic and clinical characteristics of 44 patients with $\mathrm{GH}$-secreting pituitary adenomas

\begin{tabular}{lccl}
\hline \multicolumn{1}{c}{ Characteristic } & First-Time Surgery & Reoperation & p Value \\
\hline Age, yrs & $49.1 \pm 15.7$ & $34.3 \pm 12.8$ & $0.007^{*}$ \\
\hline Sex & & & 0.29 \\
\hline Female & $21(60 \%)$ & $4(36.4 \%)$ & \\
\hline Male & $14(40 \%)$ & $7(63.6 \%)$ & \\
\hline Preop GH, $\mu$ g/L & $25.6 \pm 36.8$ & $7.7 \pm 13.1$ & $0.04^{*}$ \\
\hline Preop IGF-I, $\mu$ g/L & $737 \pm 340$ & $745 \pm 375$ & 0.94 \\
\hline Preop hormonal deficits & $3(9.1 \%)$ & $3(27.2 \%)$ & 0.31 \\
\hline Tumor size & $16.9 \pm 11.9$ & $14.8 \pm 10.0$ & 0.574 \\
\hline Microadenomas & $13(37.1 \%)$ & $5(45.5 \%)$ & 0.73 \\
\hline Macroadenomas & $22(62.9 \%)$ & $6(54.5 \%)$ & \\
\hline Knosp classification & & & 0.468 \\
\hline Grade 0 & $3(8.6 \%)$ & $1(9.1 \%)$ & \\
\hline Grade I & $14(40 \%)$ & $4(36.4 \%)$ & \\
\hline Grade II & $8(22.9 \%)$ & $1(9.1 \%)$ & \\
\hline Grade IIIA & $2(5.7 \%)$ & $1(9.1 \%)$ & \\
\hline Grade IIIB & $3(8.6 \%)$ & $1(9.1 \%)$ & \\
\hline Grade IV & $5(14.3 \%)$ & $3(27.3 \%)$ & \\
\hline CS invasion & $10(28.6 \%)$ & $5(45.5 \%)$ & 0.46 \\
\hline CS Gavenous & & &
\end{tabular}

CS = cavernous sinus.

Two of the 44 patients are included in both the first-time surgery group and the reoperation group. Values for continuous variables are means \pm SD. Values for categorical variables are numbers of tumors or patients $(\%)$.

* Statistically significant.

had previously been treated with transsphenoidal surgery. In that group, there was 1 patient $(9 \%)$ who had undergone a combination of multiples surgeries (1 craniotomy and 1 transsphenoidal procedure), radiotherapy, and medical therapy, and 6 patients (54.4\%) who had received adjuvant medical therapy. The mean interval between the first surgical procedure and reoperation in our department was 38.9 months (range 8-144 months). Immunohistochemical analysis demonstrated a GH-PRL co-secreting tumor in 2 reoperation cases $(18.2 \%)$. Preoperative characteristics of the first-time surgery and reoperation groups are presented in Table 1. While tumor size and cavernous sinus invasion were similar, significant differences between the 2 groups were found for age (first-time operation $49.1 \pm$ 15.7 years vs reoperation $34.3 \pm 12.8$ years, $\mathrm{p}=0.007$ ) and preoperative $\mathrm{GH}$ levels (first-time operation $25.6 \pm 36.8$ $\mu \mathrm{g} / \mathrm{L}$ vs reoperation $7.7 \pm 13 \mu \mathrm{g} / \mathrm{L}, \mathrm{p}=0.04)$.

\section{Surgical Results}

For reoperations, hormonal control after surgical treatment was achieved in 7 patients $(63.6 \%)$ who underwent reoperation. Although the disease control rate after reoperation was better for patients with microadenomas $(80 \%)$ than for those with macroadenomas (50\%), no statistical significant difference was observed $(\mathrm{p}=0.54)$. Tumors with cavernous sinus invasion were associated with worse disease control rates $(\mathrm{p}=0.01)$ (Table 2$)$. The mean preoperative $\mathrm{GH}$ level was $3.72 \pm 2.98 \mu \mathrm{g} / \mathrm{L}$ in patients with hormonal control compared with $23.8 \pm 21.9 \mu \mathrm{g} / \mathrm{L}$ for those
TABLE 2. Predictors of disease control: univariate analysis

\begin{tabular}{|c|c|c|c|}
\hline Variable & $\begin{array}{l}\text { Controlled } \\
\text { Disease }\end{array}$ & $\begin{array}{c}\text { Active } \\
\text { Disease }\end{array}$ & $\begin{array}{c}p \\
\text { Value }\end{array}$ \\
\hline First-time surgery $(n=35)$ & $25(71.4 \%)$ & $10(28.6 \%)$ & \\
\hline Age, yrs & $52.4 \pm 15.3$ & $39.9 \pm 13.4$ & $0.03^{*}$ \\
\hline Sex & $10 \mathrm{M} / 15 \mathrm{~F}$ & $4 \mathrm{M} / 6 \mathrm{~F}$ & 0.678 \\
\hline Preop GH, $\mu \mathrm{g} / \mathrm{L}$ & $16.9 \pm 25.5$ & $57.7 \pm 55.0$ & $0.01^{*}$ \\
\hline Preop IGF-I, $\mu \mathrm{g} / \mathrm{L}$ & $657 \pm 300$ & $1021 \pm 340$ & $0.01^{*}$ \\
\hline Tumor size, mm & $11.6 \pm 4.23$ & $31.1 \pm 12.8$ & $0.001^{*}$ \\
\hline Microadenomas & 12 & 1 & 0.055 \\
\hline Macroadenomas & 13 & 9 & \\
\hline CS invasion & 2 & 8 & $0.001^{*}$ \\
\hline Reoperation $(n=11)$ & $7(63.6 \%)$ & $4(36.3 \%)$ & \\
\hline Age, yrs & $35.5 \pm 14.2$ & $32.7 \pm 9.17$ & 0.77 \\
\hline Sex & $4 \mathrm{M} / 3 \mathrm{~F}$ & $3 \mathrm{M} / 1 \mathrm{~F}$ & 0.53 \\
\hline Preop GH, $\mu \mathrm{g} / \mathrm{L}$ & $3.72 \pm 2.98$ & $23.8 \pm 21.9$ & 0.18 \\
\hline Preop IGF-I, $\mu \mathrm{g} / \mathrm{L}$ & $694 \pm 379$ & $867 \pm 414$ & 0.66 \\
\hline Tumor size, mm & $12.1 \pm 8.8$ & $19.5 \pm 11.7$ & 0.26 \\
\hline Microadenomas & 4 & 1 & 0.54 \\
\hline Macroadenomas & 3 & 3 & \\
\hline CS invasion & 1 & 4 & $0.01^{*}$ \\
\hline Total series $(n=44) \dagger$ & $32(69.1 \%)$ & $14(30.4 \%)$ & \\
\hline Age, yrs & $48.6 \pm 16.7$ & $37.8 \pm 12.5$ & $0.03^{*}$ \\
\hline Sex & $14 \mathrm{M} / 18 \mathrm{~F}$ & $7 \mathrm{M} / 7 \mathrm{~F}$ & 0.75 \\
\hline Preop GH, $\mu g / L$ & $13.4 \pm 22.5$ & $49.2 \pm 50.3$ & $0.005^{*}$ \\
\hline Preop IGF-I, $\mu \mathrm{g} / \mathrm{L}$ & $665 \pm 313$ & $974 \pm 347$ & $0.011^{*}$ \\
\hline Tumor size, mm & $11.7 \pm 5.38$ & $27.7 \pm 13.2$ & $0.001^{*}$ \\
\hline Microadenomas & 16 & 2 & $0.02^{*}$ \\
\hline Macroadenomas & 16 & 12 & \\
\hline CS invasion & 3 & 12 & $0.001^{*}$ \\
\hline \multicolumn{4}{|c|}{$\begin{array}{l}\text { Values are means } \pm \text { SD or numbers of tumors or patients (\%) unless otherwise } \\
\text { specified. } \\
\text { * Statistically significant. } \\
\dagger \text { Two patients who underwent first-time surgery in our center also underwent } \\
\text { reoperation there. Characteristics of those patients for the first surgery and } \\
\text { reoperation are included in the total series analysis (i.e., treated as separate } \\
\text { cases). }\end{array}$} \\
\hline
\end{tabular}

without hormonal control, although the difference was not statistically significant, presumably due to the small numbers of patients in the group.

The first-time surgery cohort had an overall rate of hormonal control (25 [71.4\%] of 35 patients) similar to that of the reoperation group $(\mathrm{p}=0.71)$. Cases involving microadenomas also had a trend toward higher likelihood of hormonal control in this population $(92.3 \%$ vs $59 \%, \mathrm{p}=$ $0.055)$. In this group, older age, smaller tumor size, lower preoperative GH and IGF-I levels, and absence of cavernous sinus invasion were associated with increased disease control (Table 2).

In the overall cohort, disease control was significantly associated with older age, absence of cavernous sinus invasion, lower preoperative GH and IGF-I levels, and small tumor size (Table 2). Analysis of outcome according to the Knosp Classification of cavernous sinus invasion showed 

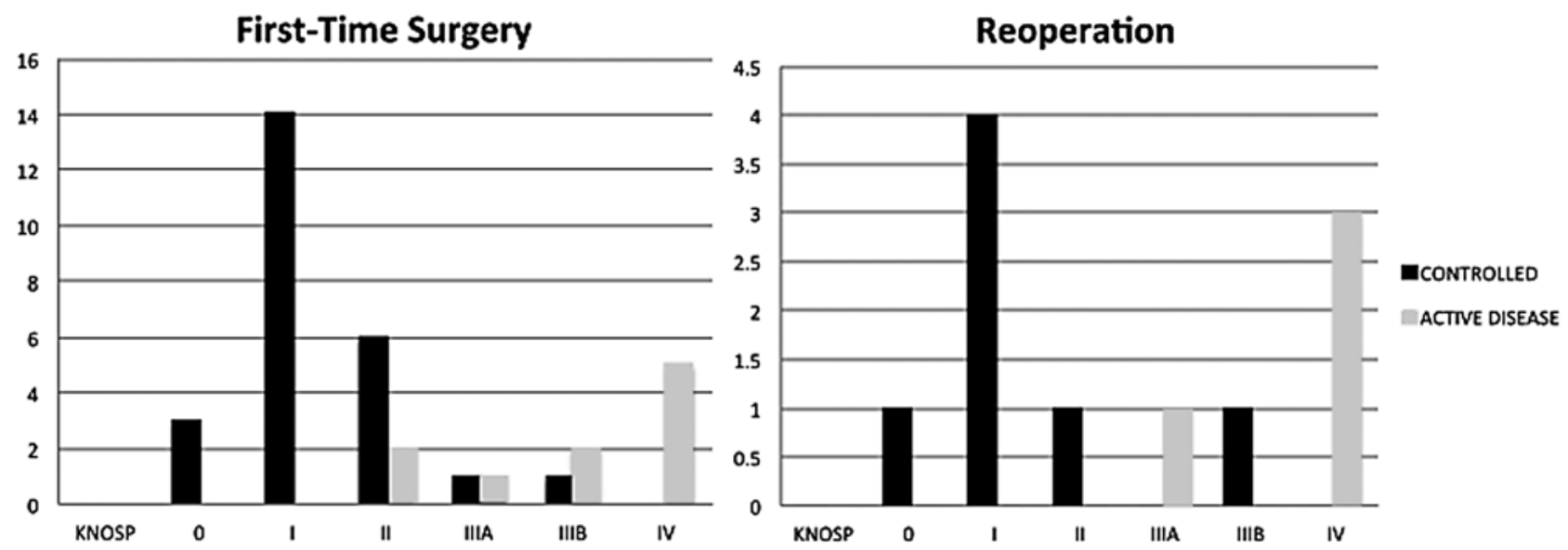

FIG. 2. Tumor Knosp grades for patients undergoing first-time surgery and reoperations. The negative impact of cavernous sinus invasion on surgical outcome is demonstrated.

that hormonal control was achieved in all Knosp Grade 0 and I cases and in 7 of 9 Knosp Grade II cases. Control was achieved in $1(33.3 \%)$ of 3 cases of Grade IIIA adenomas and $2(50 \%)$ of 4 cases of Grade IIIB lesions. Patients with Grade IV adenomas had the worst clinical results and surgery did not provide control of any of the tumors of this Knosp grade (Fig. 2).

\section{Complications}

After reoperation, 1 patient developed transient DI and hypogonadism (1 [9\%] of 11 cases). There was no postoperative CSF leak, meningitis, carotid injury, or cranial nerve palsy in this cohort.

In the first-time surgery group, postoperative hormonal dysfunctions were also uncommon, but they were more prevalent than in the reoperation group $(\mathrm{n}=5,15.1 \%)$; hypopituitarism was observed in 2 patients, DI and panhypopituitarism in 1 patient, and transient DI in 2 patients. There was 1 intrasellar hematoma after resection of a large macroadenoma, which was treated with reoperation. This patient presented with a transient third cranial nerve palsy after surgery. Another patient with a large adenoma invading the cavernous sinus also had transient diplopia secondary to postoperative oculomotor nerve dysfunction. Both patients had improvement of the cranial nerve palsy observed during follow-up. One patient had a postoperative CSF leak that was successfully treated with a lumbar drain during the first years of this surgical series. No patients died.

\section{Management of Patients With Active Disease}

In 4 patients $(36.3 \%)$ who underwent reoperation, disease control was not achieved after surgery. In 3 cases, medical therapy was applied, and disease control was achieved in one of these cases after introduction of octreotide. Two patients had residual tumor in the lateral compartment of the cavernous sinus and were referred to radiosurgery for adjuvant treatment, with successful disease control in both cases - after 2 years in one case and 3 years in the other case. One patient with a Knosp IV adenoma had a postoperative $\mathrm{GH}$ level of $1.4 \mu \mathrm{g} / \mathrm{L}$ and normal IGF-I level, and it was decided to follow this patient with laboratory testing for evaluation of disease control before reintroduction of medical therapy.

In 10 patients $(28.6 \%)$ in the first-time surgery group, long-term hormonal control was not achieved after surgery. Two of these patients underwent reoperations through an EEA and 1 patient required a craniotomy for resection of residual tumor involving the lateral wall of the cavernous sinus, which was causing diplopia and progressive visual deterioration; 5 patients were treated with medical therapy (cabergoline and octreotide in 3 cases and only octreotide in 2 cases) and 4 were referred for radiosurgical treatment. At last follow-up, 6 of these 10 patients had achieved disease control according to hormonal evaluation (60\%).

\section{Systematic Review}

A total of 78 published studies were identified through our initial search. After careful scrutiny of these studies, 49 were rejected from our review because they did not include original data, did not specify the criteria for disease control, did not report outcomes, or presented results of a mixed population of patients undergoing first-time surgery and reoperations. Five papers dedicated to analysis of reoperations were included., 2,18,37,63,64 For first-time surgery analysis, 10 transsphenoidal microsurgical studies, ${ }^{11,14,16}$, 33-36,38,49,55 11 endoscopic endonasal studies, 5,10,15,19,26,29,48, $60-62,66$ and 3 papers with results of both approaches ${ }^{13,20,52}$ were selected. A total of 29 studies were included in this review. All were retrospective clinical series. Characteristics of studies included in this review are presented in Tables 3 and 4.

In the reoperation cohort, there were 161 patients included for analysis; their mean age was 42 years and the mean duration of follow-up was 53.7 months (range 3-144 months). Patients who underwent transsphenoidal microsurgical treatment accounted for most of this group (138 patients extracted from 3 studies). Tumors were classified as micro- or macroadenomas in 4 series (147 patients); in those studies macroadenomas represented $72.8 \%$ (107 macroadenomas) of the tumors. Cavernous sinus invasion was reported in 4 studies and occurred in $32 \%$ of tumors 
TABLE 3. Population characteristics: reoperation studies

\begin{tabular}{|c|c|c|c|c|c|c|c|c|c|}
\hline $\begin{array}{l}\text { Authors } \\
\& \text { Year }\end{array}$ & $\begin{array}{c}\text { No. } \\
\text { of } \\
\text { Pts }\end{array}$ & $\begin{array}{c}\text { Mean Age } \\
(y r s)\end{array}$ & $\begin{array}{l}\text { Surgical } \\
\text { Approach }\end{array}$ & $\begin{array}{c}\text { Criteria for } \\
\text { Hormonal } \\
\text { Control }\end{array}$ & $\begin{array}{l}\text { Mean Tumor } \\
\text { Size } \\
(\mathrm{mm})\end{array}$ & Microadenomas & Macroadenomas & $\begin{array}{c}\text { CS } \\
\text { Invasion }\end{array}$ & $\begin{array}{c}\text { FU } \\
\text { (mos) }\end{array}$ \\
\hline Kurosaki et al., 2003 & 32 & $43(26-64)$ & Micro & 2000 guidelines* & $20.2(11-46)$ & $10(31.2 \%)$ & $22(68.7 \%)$ & $6(18.7 \%)$ & 48 \\
\hline $\begin{array}{l}\text { Espinosa de los Mon- } \\
\text { teros et al., } 2009\end{array}$ & 53 & $38.2 \pm 12.0$ & Micro & 2000 guidelines & NA & $4(8 \%)$ & $49(92.4 \%)$ & $12(23 \%)$ & NA \\
\hline Yamada et al., 2010 & 53 & $41.7 \pm 1.9$ & Micro & 2000 guidelines & NA & $22(41.5 \%)$ & $31(58.4 \%)$ & $25(47.1 \%)$ & $56(12-144)$ \\
\hline Alahmadi et al., 2012 & 9 & $50(20-79)$ & Endo & 2000 guidelines & NA & $4(44.4 \%)$ & $5(55.6 \%)$ & $4(44 \%)$ & $21(3-64)$ \\
\hline Wilson et al., 2013 & 14 & $41.4 \pm 13.3$ & Endo & 2010 guidelines & $13.4 \pm 7.8$ & NA & NA & NA & NA \\
\hline Total & 161 & $42 \pm 5.5$ & $\begin{array}{l}\text { Endo \& } \\
\text { Micro }\end{array}$ & - & 18.1 & $40(27.2 \%)$ & $107(72.8 \%)$ & $47(32 \%)$ & $53.7(3-144)$ \\
\hline Current series & 11 & $34.3 \pm 12.8$ & Endo & 2010 guidelines & $14.8 \pm 10.0$ & $5(45.4 \%)$ & $6(54.6 \%)$ & $5(45.4 \%)$ & $70(6-150)$ \\
\hline
\end{tabular}

Endo = endoscopy; FU = follow-up; micro = microsurgery; $\mathrm{NA}=$ not available; pts = patients.

* The 2000 guidelines are also known as the Cortina criteria.

(Table 3). Mean tumor size was rarely reported (2 series, 46 patients, mean tumor size $18.1 \mathrm{~mm}$ ).

There were 2189 patients included in the first-time surgery group, with a mean age of 44.4 years (Table 4 ). The transsphenoidal microsurgical approach was used in 1531 patients (69.9\%) and EEA in 658 patients $(30.1 \%)$. There was a trend toward longer follow-up in microsurgical series (mean 44.2 months, range 6-372 months) than in endoscopic series (mean 28 months, range 6-156 months) in this group, but this finding was without statistical significance $(\mathrm{p}=0.381)$. The duration of follow-up was similar in the first-time surgery (mean 41.5 months, range 6-372 months) and reoperation (mean 53.7 months, range 3-144 months) groups. Twenty-two first-time surgery studies classified tumors as microadenomas (504 cases, 23.9\%) or macroadenomas (1604 cases, $76.1 \%$ ), presenting a distribution similar to that for reoperations. Cavernous sinus invasion, which was reported in 18 papers, occurred in 312 of 1164 cases $(26.1 \%)$ and was more commonly observed in endoscopic series (108 [17.8\%] of 605 microsurgical cases vs 204 [36.4\%] of 559 endoscopic cases, $\mathrm{p}=0.001$ ). There was no significant difference with respect to cavernous sinus invasion between the reoperation and firsttime surgery groups (47 [32\%] of 147 vs 312 [26.8\%] of 1164 cases, $\mathrm{p}=0.20)$. Mean tumor size was described in 8 series (1012 patients, mean tumor size $13.4 \pm 3.4 \mathrm{~mm}$ ). Because of the paucity of mean tumor size data in reoperation studies, statistical analysis was not performed on this variable.

\section{Surgical Results}

Reoperation achieved disease control in $46.8 \%$ of patients (95\% CI 20\%-74\%) (Fig. 3), with disease control in $52 \%(95 \%$ CI $32 \%-71 \%$ ) (Table 5) of patients in endoscopy studies and $44.5 \%$ (95\% CI 9\%-82\%) in microsurgical studies. According to tumor size, microadenomas had a better disease control rate than macroadenomas $(73.6 \%$ [95\% CI $32 \%-98 \%$ ] vs $27.4 \%$ [95\% CI 5\%-57\%]). Disease control was achieved in only $14.7 \%(95 \% \mathrm{CI}=0.04$ to 0.29 ) of tumors with cavernous sinus invasion. Only one study ${ }^{63}$ used the 2010 criteria for disease control, and it had a control rate similar to that for studies that used the 2000 criteria.

The first-surgery group had a disease control rate of $56.4 \%$ (95\% CI 49\%-63\%) (Fig. 4). Microadenomas had better disease control rates than macroadenomas $(77.7 \%$ [95\% CI $68 \%-85 \%$ ] vs $54.2 \%$ [ $95 \%$ CI $45 \%$ to $62 \%$ ], respectively), whereas endoscopy had a tendency toward higher control rates than microsurgery $(58.7 \%$ [95\% CI $47 \%-69 \%$ ] vs $51.7 \%$ [95\% CI $42 \%$ to $60 \%]$ ). Tumor that presented with invasion of the cavernous sinus had a lower disease control rate (38.5\% [95\% CI 27\%-50\%]). The 2010 criteria were applied in 10 studies (532 patients) in the first-time surgery group. In this subgroup, disease control was achieved in 300 cases (56.3\%).

\section{Complications}

Patients who underwent reoperation and those who underwent first-time surgery had overall similar rates of postoperative CSF leaks, meningitis, cranial nerve palsy, DI, hypopituitarism, and rhinological complications (Fig. 5).

\section{Discussion}

Management of newly diagnosed acromegaly is based on relatively well-established concepts. Resection of GHsecreting adenomas remains the gold standard therapy for acromegaly, with a mean historical control rate for firsttime surgery of $56.4 \%$ according to our meta-analysis. Successful transsphenoidal surgery, via an endoscopic or microsurgical technique, is associated with improvement of symptoms secondary to decreased tumor mass effect and rapid decline of GH and IGF-I levels. ${ }^{6,19,26,32,44}$ For cases in which gross-total tumor resection is unlikely, such as those with complete carotid artery encasement, neoadjuvant medical therapy might be introduced in an attempt to reduce tumor size and control symptoms prior to resection. However, even for those cases, there is evidence that primary surgical debulking may lead to improved control rates after medication is introduced. $., 24,32,44$

Treatment of recurrent or persistent acromegaly after an initial surgery, however, is more complex. While medi- 
TABLE 4. Population characteristics: first-time surgery studies

\begin{tabular}{|c|c|c|c|c|c|c|c|c|c|}
\hline $\begin{array}{l}\text { Authors } \\
\& \text { Year }\end{array}$ & $\begin{array}{c}\text { No. } \\
\text { of } \\
\text { Pts }\end{array}$ & $\begin{array}{l}\text { Mean } \\
\text { Age } \\
\text { (yrs) }\end{array}$ & $\begin{array}{l}\text { Surgical } \\
\text { Approach }\end{array}$ & $\begin{array}{c}\text { Criteria for } \\
\text { Hormonal } \\
\text { Control }\end{array}$ & $\begin{array}{l}\text { Mean } \\
\text { Tumor } \\
\text { Size } \\
(\mathrm{mm})\end{array}$ & Microadenomas & Macroadenomas & CS Invasion & $\begin{array}{l}\text { FU in } \\
\text { Months } \\
\text { (range) }\end{array}$ \\
\hline $\begin{array}{l}\text { Kreutzer et al., } \\
2001\end{array}$ & 57 & 43.9 & Micro & 2000 guidelines & NA & $19(33.3 \%)$ & $38(66.7 \%)$ & NA & $37.7(12-88)$ \\
\hline De et al., 2003 & 90 & 61 & Micro & 2000 guidelines & NA & $29(32.2 \%)$ & $61(67.7 \%)$ & NA & $10.9(6-240)$ \\
\hline $\begin{array}{l}\text { Chandna et al., } \\
2004\end{array}$ & 30 & 35.6 & Micro & 2000 guidelines & NA & $5(16.6 \%)$ & $25(83.3 \%)$ & $3(10 \%)$ & NA \\
\hline $\begin{array}{l}\text { Nomikos et al., } \\
2005\end{array}$ & 506 & 42.3 & Micro & 2000 guidelines & 15.8 & $142(28 \%)$ & $364(71.9 \%)$ & NA & 146 \\
\hline $\begin{array}{l}\text { Krzentowska-Korek } \\
\text { et al., } 2011\end{array}$ & 85 & 43.9 & Micro & 2000 guidelines & 13.1 & $19(22.3 \%)$ & $66(77.6 \%)$ & NA & NA \\
\hline Ku et al., 2012 & 282 & 41.8 & Micro & 2000 guidelines & NA & $75(26.5 \%)$ & 207 (73.4\%) & $48(17 \%)$ & $6.7(1.5-18.7)$ \\
\hline Demır et al., 2012 & 180 & 44 & Micro & 2000 guidelines & NA & $51(28.3 \%)$ & $129(71.6 \%)$ & NA & $8(6-372)$ \\
\hline $\begin{array}{l}\text { Lampropoulos et } \\
\text { al., } 2013\end{array}$ & 51 & 44.61 & Micro & 2010 guidelines & 13.5 & $10(19.6 \%)$ & $41(80.3 \%)$ & $17(33 \%)$ & 43 \\
\hline Shirvani et al., 2014 & 130 & 39.6 & Micro & 2000 guidelines & NA & $38(29.2 \%)$ & $92(70.7 \%)$ & $5(3.7 \%)$ & $35.9(6-169)$ \\
\hline Choe et al., 2008* & 8 & 47 & Micro & 2000 guidelines & NA & $1(12.5 \%)$ & $7(8.75 \%)$ & NA & NA \\
\hline Kim et al., 2009 & 42 & 40.2 & Micro & 2000 guidelines & NA & $12(28.5 \%)$ & $30(71.4 \%)$ & $10(23.8 \%)$ & $49.4(3-178)$ \\
\hline Sarkar et al., 2014* & 47 & 38.7 & Micro & 2010 guidelines & 19.7 & $8(17 \%)$ & $39(82.9 \%)$ & $17(36.2 \%)$ & 49.2 \\
\hline $\begin{array}{l}\text { Fathalla et al., } \\
\qquad 2015^{*}\end{array}$ & 23 & 42.1 & Micro & 2010 guidelines & NA & $6(26.1 \%)$ & $17(73.9 \%)$ & $8(34.7 \%)$ & $56.6(6-156)$ \\
\hline $\begin{array}{l}\text { Cappabianca et al., } \\
2002\end{array}$ & 23 & NA & Endo & 2000 guidelines & NA & $3(15 \%)$ & $20(86.9 \%)$ & NA & NA \\
\hline $\begin{array}{l}\text { Esposito et al., } \\
2004\end{array}$ & 67 & 43.2 & Endo & 2010 guidelines & NA & NA & NA & NA & 31 \\
\hline $\begin{array}{l}\text { Dehdashti et al., } \\
2008\end{array}$ & 34 & 49.9 & Endo & 2000 guidelines & NA & $8(23.5 \%)$ & $26(76.4 \%)$ & $4(11.7 \%)$ & 20 \\
\hline Choe et al., 2008* & 9 & 47 & Endo & 2000 guidelines & NA & $1(11.2 \%)$ & $8(88.8 \%)$ & NA & NA \\
\hline Ceylan et al., 2010 & 7 & NA & Endo & 2000 guidelines & NA & NA & NA & 7 & $24.4(18-45)$ \\
\hline $\begin{array}{l}\text { Gondim et al., } \\
2010^{26}\end{array}$ & 67 & 44.8 & Endo & 2000 guidelines & 21.5 & $14(20.8 \%)$ & $53(79.1 \%)$ & $12(17.9 \%)$ & $24(12-72)$ \\
\hline $\begin{array}{l}\text { Hofstetter et al., } \\
2010\end{array}$ & 24 & 50.7 & Endo & 2010 guidelines & NA & $4(20 \%)$ & $20(80 \%)$ & $10(41.7 \%)$ & 23.2 \\
\hline $\begin{array}{l}\text { Wagenmakers et } \\
\text { al., } 2011\end{array}$ & 40 & 47 & Endo & 2000 guidelines & 18.9 & $3(7.5 \%)$ & $37(92.5 \%)$ & 17 & 56 \\
\hline Wang et al., 2012 & 43 & 49 & Endo & 2010 guidelines & NA & $13(43.3 \%)$ & $30(69.7 \%)$ & $12(27.9 \%)$ & 34 \\
\hline $\begin{array}{l}\text { van Bunderen et } \\
\text { al., } 2013\end{array}$ & 30 & 43.6 & Endo & 2010 guidelines & NA & $3(10 \%)$ & $27(90 \%)$ & $20(67 \%)$ & 14 \\
\hline Yildirim et al., 2014 & 56 & 42.3 & Endo & 2010 guidelines & NA & $5(9.8 \%)$ & $51(91.2 \%)$ & $10(18.8 \%)$ & 18 \\
\hline $\begin{array}{l}\text { Nishioka et al., } \\
2014\end{array}$ & 150 & 47 & Endo & 2010 guidelines & 17.8 & $17(12.7 \%)$ & $133(88.6 \%)$ & $55(36.7 \%)$ & $22(11-34)$ \\
\hline Sarkar et al., 2014* & 66 & 37.6 & Endo & 2010 guidelines & 22.0 & $8(12.1 \%)$ & $58(87.9 \%)$ & $32(48.9 \%)$ & 22.38 \\
\hline $\begin{array}{l}\text { Fathalla et al., } \\
\qquad 2015^{*}\end{array}$ & 42 & 43.2 & Endo & 2010 guidelines & NA & $7(17 \%)$ & $35(83 \%)$ & $25(59.5 \%)$ & $56.6(6-156)$ \\
\hline Total & 2189 & $44.4 \pm 5.06$ & $\begin{array}{l}\text { Endo \& } \\
\text { Micro }\end{array}$ & - & $17.1 \pm 3.2$ & $504(23.9 \%) \dagger$ & $1604(76.1 \%) \dagger$ & $312(26.8 \%) \dagger$ & $41.5(6-372)$ \\
\hline
\end{tabular}

* Studies that included patients treated via endoscopic and microsurgical approaches.

† Data not available for all studies. 


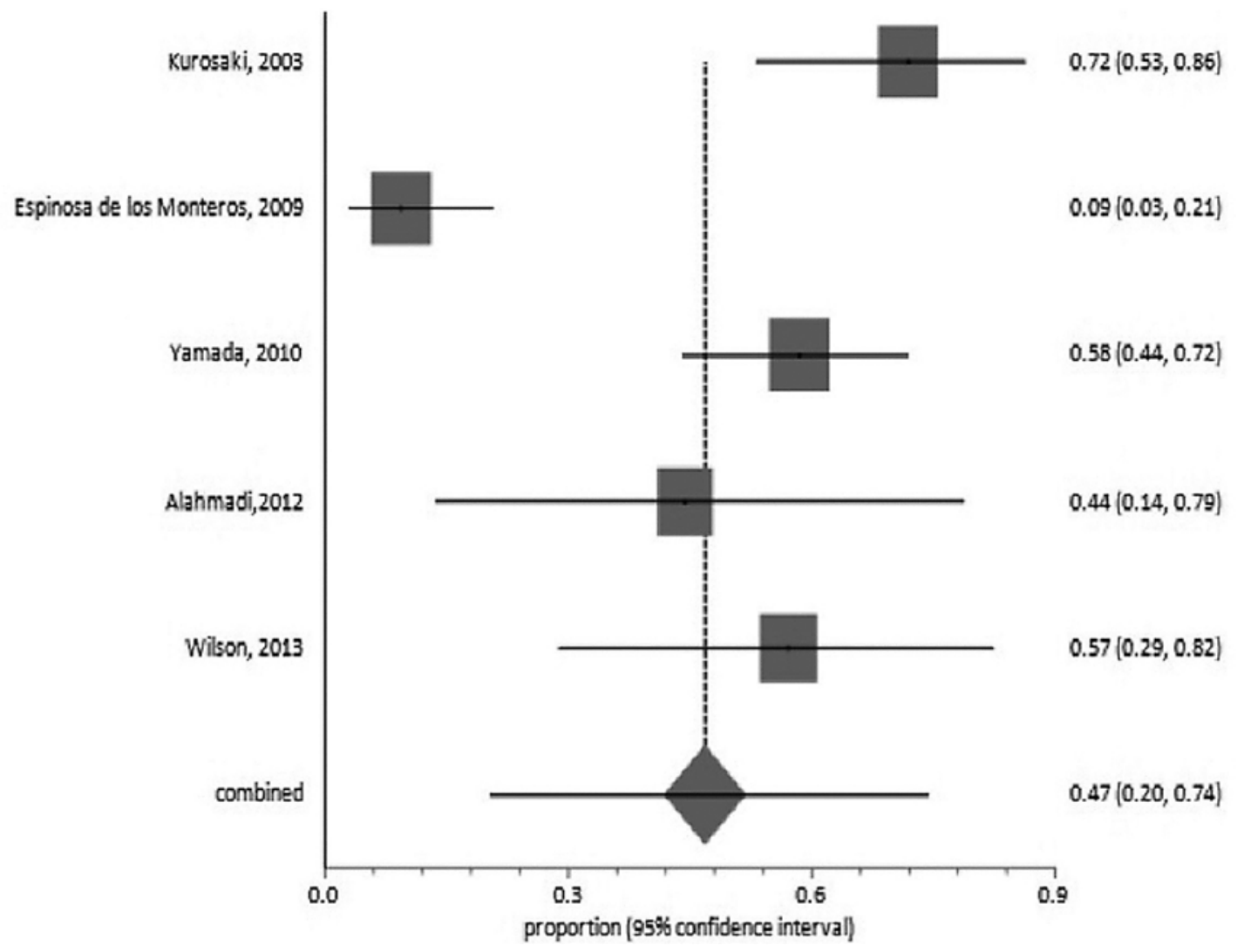

FIG. 3. Disease control achieved with reoperation according to the meta-analysis.

cal therapy plays a major role in those cases,${ }^{24}$ it requires long-term use of medications that may be associated with significant side effects and financial burden. Somatostatin receptor ligands (SRLs), such as octreotide and lanreotide, represent the first line of medical treatment, with disease control achieved in approximately 25\% of nonselected patients $^{17,24,32,44}$ and reduction of tumor volume in $53 \% .^{25}$ Pasireotide, a new SRL, has been associated with control rates of $35 \%$, while pegvisomant led to biochemical remission according to IGF-I levels in $67 \%$ of treated patients. ${ }^{21}$ Side effects, such as gastrointestinal symptoms, cholelithiasis, hyperglycemia, and hepatotoxicity, may limit the benefits of those drugs. ${ }^{32,45}$ Radiosurgery has been advocated in selected cases in which a small residual lesion is observed and in those with cavernous sinus invasion. However, disease control may require up to 3-5 years to be achieved, and side effects such as visual deterioration and anterior pituitary hormone deficiency may occur in up to $11 \%$ and $47 \%$ of cases, respectively. ${ }^{57}$

Reoperation for GH-secreting tumors has been infrequently studied, although surgical advances, such as the development of EEA, have become an important part of the treatment of residual/recurrent pituitary adenomas. According to our inclusion criteria, only 5 clinical series have reported results of reoperation for acromegaly that clearly separated reoperations from first-time surgeries. ${ }^{31,54,58}$ Pooled results for reoperation demonstrated $46.8 \%$ disease control, with a wide range of results (Fig. 4). Since treatment of persistent acromegaly is based on multimodal therapy and none of the included studies were randomized, it is possible that this heterogeneity in the results reflects a certain degree of selection bias and differences in surgical expertise.

In our reoperation series, an overall control rate of $63.6 \%$ was achieved, similar to the control rate for firsttime surgery in our series $(71.4 \%, \mathrm{p}=0.71)$, and better than the average reoperation control rate observed in the metaanalysis (46.8\%). Moreover, most of these prior publications did not use the more recent and stringent 2010 criteria, so rates of control from prior series are likely lower than reported here.

Tumor size was not associated with disease control after reoperation in our series. There was a trend toward im-

TABLE 5. Meta-analysis results for reoperation and first-time surgery of $\mathrm{GH}$-secreting adenomas

\begin{tabular}{llc}
\hline \multirow{2}{*}{ Variable } & \multicolumn{2}{c}{ Disease Control Rate $(95 \% \mathrm{CI})$} \\
\cline { 2 - 3 } \multicolumn{1}{c}{ Reoperation } & First-Time Surgery \\
\hline Overall control & $46.8 \%(20-74 \%)$ & $56.4 \%(49-63 \%)$ \\
\hline Endoscopy & $52 \%(32-71 \%)$ & $58.7 \%(47-69 \%)$ \\
\hline Microsurgery & $44.5 \%(9-82 \%)$ & $51.7 \%(42-60 \%)$ \\
\hline Microadenomas & $73.6 \%(32-98 \%)$ & $77.7 \%(68-85 \%)$ \\
\hline Macroadenomas & $27.5 \%(5-57 \%)$ & $54.3 \%(45-62 \%)$ \\
\hline CS invasion & $14.7 \%(4-29 \%)$ & $38.5 \%(27-50 \%)$ \\
\hline
\end{tabular}




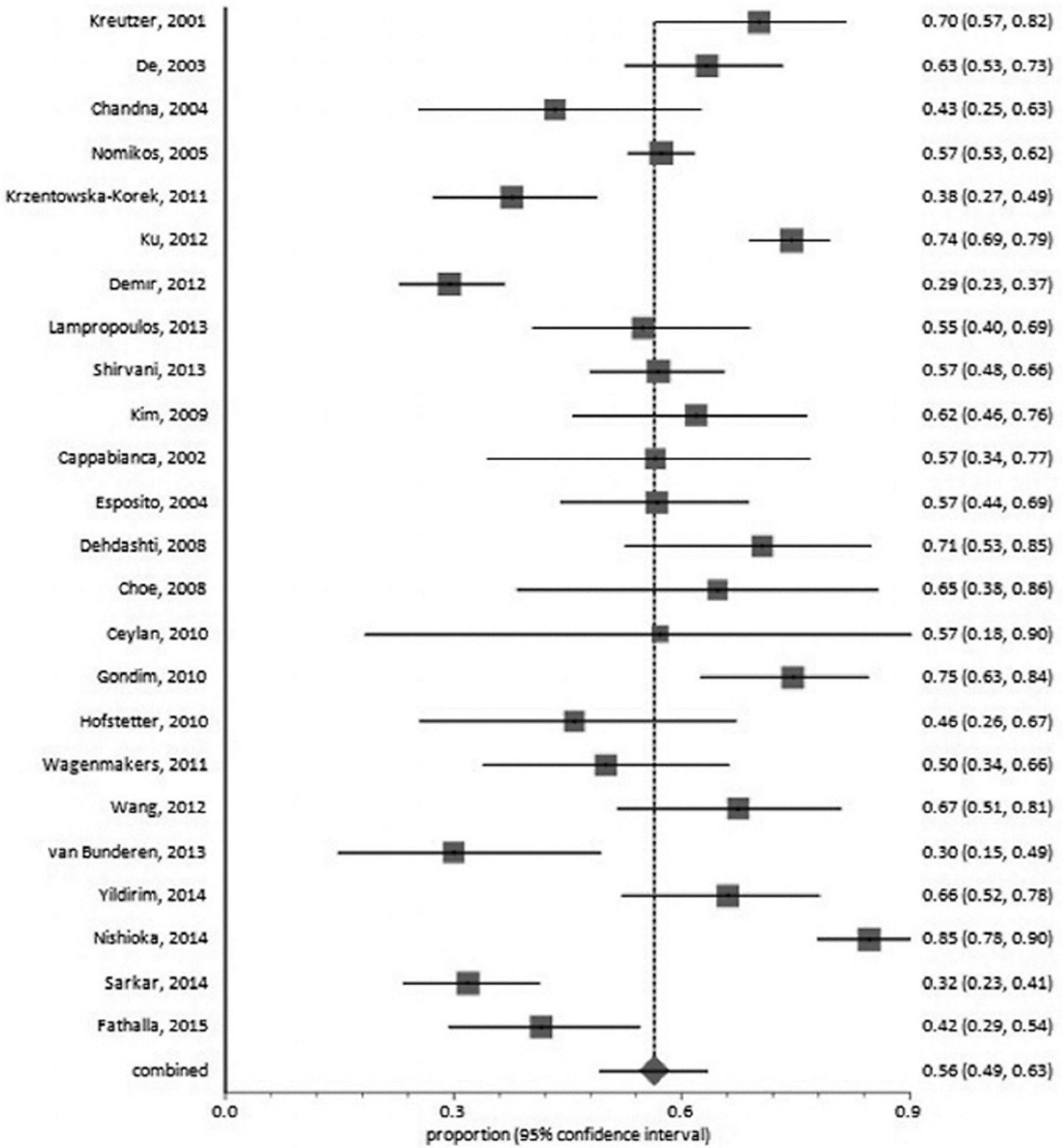

FIG. 4. Disease control achieved with first-time surgery according to the meta-analysis.

proved outcomes for treatment of macroadenomas, when compared with treatment of macroadenomas, both for first-time surgery and reoperation, but no statistical significance was observed. When compared with the meta-analysis results, our control rate for reoperated microadenomas $(80 \%)$ was similar to previously reported rates $(73.6 \%)$; however, the outcome of reoperation for macroadenoma was better in our study than in the meta-analysis (control rate $50 \%$ vs $27.4 \%$ ). These results mirror the results for other tumor types; EEA tends to make a bigger difference in the treatment of larger and more invasive adenomas than for smaller and less invasive ones since the visualization and exposure in the extended endoscopic approaches is superior. Extended approaches, such as transtuberculum/ transplanum, and extracapsular resection are performed to attempt gross-total removal and disease control in cases of large suprasellar adenomas.

Cavernous sinus invasion remains a challenge and dictates the surgical strategy for removal of those tumors. It is our philosophy to attempt "cure" for Knosp I and II 


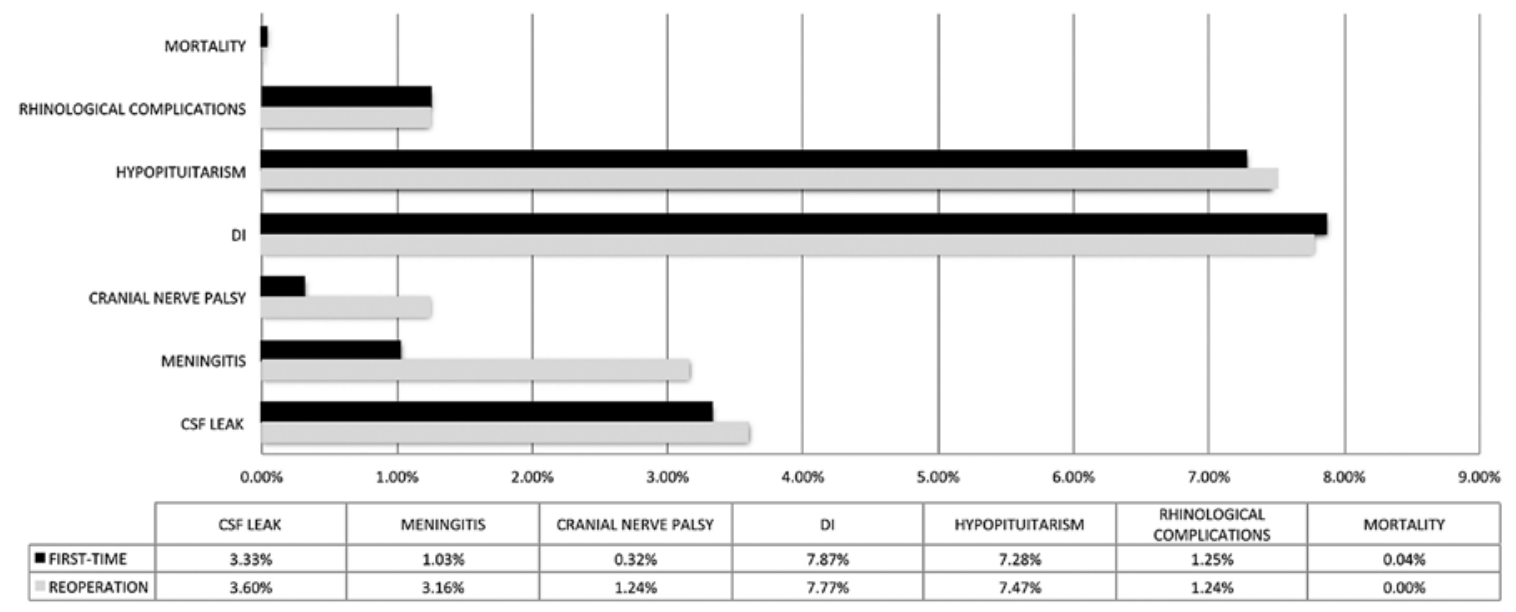

FIG. 5. Rates of surgical complications related to first-time surgery and reoperation according to the meta-analysis.

residual tumors and obtain maximal tumor debulking for Knosp III and IV lesions, in order to maximize the efficacy of subsequent medical or radiation therapy. When results of those 2 groups are analyzed (Fig. 3), it is noted that all reoperated patients without cavernous sinus invasion achieved control. For those with cavernous sinus invasion, our data suggest that patients with Knosp III adenoma may benefit from attempts at gross-total resection. Hormonal control was achieved for 1 patient with a Knosp IIIB adenoma, but no tumor with complete carotid artery encasement was completely resected in the reoperation group. A similar scenario was observed in the first-time surgery group, in which control was achieved in $92 \%$ of patients with Knosp I and II tumors, $40 \%$ of those with Knosp III tumors, and none with Knosp IV tumors. Although disease control rates for tumors with cavernous sinus invasion were similar for reoperations and first-time surgery in our series, results from the meta-analysis show that cavernous sinus invasion has been associated with worse outcome for reoperations (disease control rate of $14.7 \%$ for reoperation vs $38.5 \%$ for first-time surgery). Pituitary adenoma extensions into the sphenoid sinus and clival region have not impacted the ability to achieve gross-total resection via EEA in our experience. Therefore, those anatomical characteristics were not evaluated in our study.

Although reoperation for pituitary adenoma can be more complicated than first-time surgery based on distorted anatomical references for surgical guidance and nasal, sphenoidal, and intrasellar scar tissue, reoperation was not associated with higher complication rates than first-time surgery. Indeed, there was no carotid artery injury, CSF leak, meningitis, or cranial nerve palsy after reoperations in our series. EEA surgeries involve routine use of Doppler ultrasonographic monitoring, neuronavigation guidance, multilayer reconstruction, fluorescein injection, and lumbar drains, which may explain the current low rates of complications.

\section{Limitations}

Results from our series consist of data acquired from retrospective analysis, which has its inherent biases. Although we carefully analyzed the data of all patients included in the study, the small number of patients who underwent reoperation may limit the generalization of the results reported in our study. The systematic review and meta-analysis here reported also has its own limitations, including but not limited to 1) lack of randomized studies (only clinical series were selected); 2) heterogeneity of studies; 3) inclusion of papers with 2 different criteria for disease control (2000 and 2010 consensus statements); and 4) the limited number of publications focused on reoperations.

\section{Conclusions}

Current results demonstrate that reoperations with EEA for recurrent/persistent acromegaly resulted in remission at a rate equal to that for first-time operations and better than the rate for historical reports. These results were particularly true for macroadenomas rather than microadenomas. Cavernous sinus invasion continues to be a negative prognostic factor for disease control; however, results with EEA are improving compared with results reported in the prior literature.

\section{Acknowledgments}

Paul Christos, DrPH, and Karikey Grover, MS, were partially supported by the following grant: Clinical and Translational Science Center at Weill Cornell Medical College (UL1TR000457-06).

\section{References}

1. Abe T, Lüdecke DK: Recent results of secondary transnasal surgery for residual or recurring acromegaly. Neurosurgery 42:1013-1022, 1998

2. Alahmadi H, Dehdashti AR, Gentili F: Endoscopic endonasal surgery in recurrent and residual pituitary adenomas after microscopic resection. World Neurosurg 77:540-547, 2012

3. Barkan A, Bronstein MD, Bruno OD, Cob A, Espinosa-delos-Monteros AL, Gadelha MR, et al: Management of acromegaly in Latin America: expert panel recommendations. Pituitary 13:168-175, 2010

4. Bronstein MD: Optimizing acromegaly treatment. Front Horm Res 38:174-183, 2010 
5. Cappabianca P, Cavallo LM, Colao A, Del Basso De Caro M, Esposito F, Cirillo S, et al: Endoscopic endonasal transsphenoidal approach: outcome analysis of 100 consecutive procedures. Minim Invasive Neurosurg 45:193-200, 2002

6. Cappabianca P, Cavallo LM, Solari D, Esposito F: Endoscopic endonasal transsphenoidal approach to pituitary adenomas. J Neurosurg 122:473-474, 2015

7. Cappabianca P, Cavallo LM, Solari D, Stagno V, Esposito F, de Angelis M: Endoscopic endonasal surgery for pituitary adenomas. World Neurosurg 82 (6 Suppl):S3-S11, 2014

8. Carrau RL, Kassam AB, Snyderman CH: Pituitary surgery. Otolaryngol Clin North Am 34:1143-1155, ix, 2001

9. Castinetti F, Morange I, Dubois N, Albarel F, Conte-Devolx $\mathrm{B}$, Dufour H, et al: Does first-line surgery still have its place in the treatment of acromegaly? Ann Endocrinol (Paris) 70:107-112, 2009

10. Ceylan S, Koc K, Anik I: Endoscopic endonasal transsphenoidal approach for pituitary adenomas invading the cavernous sinus. J Neurosurg 112:99-107, 2010

11. Chandna A, Islam N, Jabbar A, Zuberi L, Haque N: Clinical features and outcome of surgery in 30 patients with acromegaly. J Pak Med Assoc 54:315-319, 2004

12. Chanson P, Salenave S, Kamenicky P, Cazabat L, Young J: Pituitary tumours: acromegaly. Best Pract Res Clin Endocrinol Metab 23:555-574, 2009

13. Choe JH, Lee KS, Jeun SS, Cho JH, Hong YK: Endocrine outcome of endoscopic endonasal transsphenoidal surgery in functioning pituitary adenomas. J Korean Neurosurg Soc 44:151-155, 2008

14. De P, Rees DA, Davies N, John R, Neal J, Mills RG, et al: Transsphenoidal surgery for acromegaly in Wales: results based on stringent criteria of remission. J Clin Endocrinol Metab 88:3567-3572, 2003

15. Dehdashti AR, Ganna A, Karabatsou K, Gentili F: Pure endoscopic endonasal approach for pituitary adenomas: early surgical results in 200 patients and comparison with previous microsurgical series. Neurosurgery 62:1006-1017, 2008

16. Demir O, Gedik V, Corapcioglu D, Emral R, Unlu MA, Erdogan MF, et al: Improvement in remission rates of the first operation in acromegalic patients. Turk Neurosurg 22:645650, 2012

17. Dineen R, Stewart PM, Sherlock M: Acromegaly. QJM [epub ahead of print], 2016

18. Espinosa de los Monteros AL, González B, Vargas G, Sosa E, Guinto G, Mercado M: Surgical reintervention in acromegaly: is it still worth trying? Endocr Pract 15:431-437, 2009

19. Esposito F, Cappabianca P, Del Basso De Caro M, Cavallo LM, Rinaldi C, De Divitiis E: Endoscopic endonasal transsphenoidal removal of an intra-suprasellar schwannoma mimicking a pituitary adenoma. Minim Invasive Neurosurg 47:230-234, 2004

20. Fathalla H, Cusimano MD, Di Ieva A, Lee J, Alsharif O, Goguen J, et al: Endoscopic versus microscopic approach for surgical treatment of acromegaly. Neurosurg Rev 38:541549, 2015

21. Freda PU, Gordon MB, Kelepouris N, Jonsson P, KoltowskaHaggstrom M, van der Lely AJ: Long-term treatment with pegvisomant as monotherapy in patients with acromegaly: experience from ACROSTUDY. Endocr Pract 21:264-274, 2015

22. Giustina A, Barkan A, Casanueva FF, Cavagnini F, Frohman L, Ho K, et al: Criteria for cure of acromegaly: a consensus statement. J Clin Endocrinol Metab 85:526-529, 2000

23. Giustina A, Chanson P, Bronstein MD, Klibanski A, Lamberts S, Casanueva FF, et al: A consensus on criteria for cure of acromegaly. J Clin Endocrinol Metab 95:3141-3148, 2010

24. Giustina A, Chanson P, Kleinberg D, Bronstein MD, Clemmons DR, Klibanski A, et al: Expert consensus document: a consensus on the medical treatment of acromegaly. Nat Rev Endocrinol 10:243-248, 2014

25. Giustina A, Mazziotti G, Torri V, Spinello M, Floriani I, Melmed S: Meta-analysis on the effects of octreotide on tumor mass in acromegaly. PLoS One 7:e36411, 2012

26. Gondim JA, Almeida JP, de Albuquerque LA, Gomes E, Schops M, Ferraz T: Pure endoscopic transsphenoidal surgery for treatment of acromegaly: results of 67 cases treated in a pituitary center. Neurosurg Focus 29(4):E7, 2010

27. Gondim JA, Ferraz T, Mota I, Studart D, Almeida JP, Gomes E, et al: Outcome of surgical intrasellar growth hormone tumor performed by a pituitary specialist surgeon in a developing country. Surg Neurol 72:15-19, 2009

28. Gondim JA, Schops M, de Almeida JP, de Albuquerque LA, Gomes E, Ferraz T, et al: Endoscopic endonasal transsphenoidal surgery: surgical results of 228 pituitary adenomas treated in a pituitary center. Pituitary 13:68-77, 2010

29. Hofstetter CP, Mannaa RH, Mubita L, Anand VK, Kennedy JW, Dehdashti AR, et al: Endoscopic endonasal transsphenoidal surgery for growth hormone-secreting pituitary adenomas. Neurosurg Focus 29(4):E6, 2010

30. Holdaway IM: Treatment of acromegaly. Horm Res 62 (Suppl 3):79-92, 2004

31. Jane JA Jr, Starke RM, Elzoghby MA, Reames DL, Payne $\mathrm{SC}$, Thorner MO, et al: Endoscopic transsphenoidal surgery for acromegaly: remission using modern criteria, complications, and predictors of outcome. J Clin Endocrinol Metab 96:2732-2740, 2011

32. Katznelson L, Laws ER Jr, Melmed S, Molitch ME, Murad $\mathrm{MH}, \mathrm{Utz}$ A, et al: Acromegaly: an endocrine society clinical practice guideline. J Clin Endocrinol Metab 99:3933-3951, 2014

33. Kim MS, Jang HD, Kim OL: Surgical results of growth hormone-secreting pituitary adenoma. J Korean Neurosurg Soc 45:271-274, 2009

34. Kreutzer J, Vance ML, Lopes MB, Laws ER Jr: Surgical management of GH-secreting pituitary adenomas: an outcome study using modern remission criteria. J Clin Endocrinol Metab 86:4072-4077, 2001

35. Krzentowska-Korek A, Gołkowski F, Bałdys-Waligórska A, Hubalewska-Dydejczyk A: Efficacy and complications of neurosurgical treatment of acromegaly. Pituitary 14:157162,2011

36. Ku CR, Kim EH, Oh MC, Lee EJ, Kim SH: Surgical and endocrinological outcomes in the treatment of growth hormone-secreting pituitary adenomas according to the shift of surgical paradigm. Neurosurgery 71 (2 Suppl Operative):ons192-ons203, 2012

37. Kurosaki M, Luedecke DK, Abe T: Effectiveness of secondary transnasal surgery in $\mathrm{GH}$-secreting pituitary macroadenomas. Endocr J 50:635-642, 2003

38. Lampropoulos KI, Samonis G, Nomikos P: Factors influencing the outcome of microsurgical transsphenoidal surgery for pituitary adenomas: a study on 184 patients. Hormones (Athens) 12:254-264, 2013

39. Laufer I, Anand VK, Schwartz TH: Endoscopic, endonasal extended transsphenoidal, transplanum transtuberculum approach for resection of suprasellar lesions. J Neurosurg 106:400-406, 2007

40. Liberati A, Altman DG, Tetzlaff J, Mulrow C, Gøtzsche PC, Ioannidis JP, et al: The PRISMA statement for reporting systematic reviews and meta-analyses of studies that evaluate health care interventions: explanation and elaboration. Ann Intern Med 151:W65-W94, 2009

41. Long H, Beauregard H, Somma M, Comtois R, Serri O, Hardy J: Surgical outcome after repeated transsphenoidal surgery in acromegaly. J Neurosurg 85:239-247, 1996

42. Mathioudakis N, Salvatori R: Management options for per- 
sistent postoperative acromegaly. Neurosurg Clin N Am 23:621-638, 2012

43. Melmed S: Medical progress: Acromegaly. N Engl J Med 355:2558-2573, 2006

44. Melmed S, Colao A, Barkan A, Molitch M, Grossman AB, Kleinberg D, et al: Guidelines for acromegaly management: an update. J Clin Endocrinol Metab 94:1509-1517, 2009

45. Melmed S, Kleinberg DL, Bonert V, Fleseriu M: Acromegaly: assessing the disorder and navigating therapeutic options for treatment. Endocr Pract 20 (Suppl 1):7-20, 2014

46. Micko AS, Wöhrer A, Wolfsberger S, Knosp E: Invasion of the cavernous sinus space in pituitary adenomas: endoscopic verification and its correlation with an MRI-based classification. J Neurosurg 122:803-811, 2015

47. Moher D, Liberati A, Tetzlaff J, Altman DG: Preferred reporting items for systematic reviews and meta-analyses: the PRISMA statement. BMJ 339:b2535, 2009

48. Nishioka H, Fukuhara N, Horiguchi K, Yamada S: Aggressive transsphenoidal resection of tumors invading the cavernous sinus in patients with acromegaly: predictive factors, strategies, and outcomes. J Neurosurg 121:505-510, 2014

49. Nomikos P, Buchfelder M, Fahlbusch R: The outcome of surgery in 668 patients with acromegaly using current criteria of biochemical 'cure'. Eur J Endocrinol 152:379-387, 2005

50. Patel KS, Komotar RJ, Szentirmai O, Moussazadeh N, Raper DM, Starke RM, et al: Case-specific protocol to reduce cerebrospinal fluid leakage after endonasal endoscopic surgery. J Neurosurg 119:661-668, 2013

51. Placantonakis DG, Tabaee A, Anand VK, Hiltzik D, Schwartz TH: Safety of low-dose intrathecal fluorescein in endoscopic cranial base surgery. Neurosurgery 61 (3 Suppl):161-166, 2007

52. Sarkar S, Rajaratnam S, Chacko G, Chacko AG: Endocrinological outcomes following endoscopic and microscopic transsphenoidal surgery in 113 patients with acromegaly. Clin Neurol Neurosurg 126:190-195, 2014

53. Schwartz TH, Anand VK: The endoscopic endonasal transsphenoidal approach to the suprasellar cistern. Clin Neurosurg 54:226-235, 2007

54. Shin SS, Tormenti MJ, Paluzzi A, Rothfus WE, Chang YF, Zainah H, et al: Endoscopic endonasal approach for growth hormone secreting pituitary adenomas: outcomes in 53 patients using 2010 consensus criteria for remission. Pituitary 16:435-444, 2013

55. Shirvani M, Motiei-Langroudi R: Transsphenoidal surgery for growth hormone-secreting pituitary adenomas in 130 patients. World Neurosurg 81:125-130, 2014

56. Singh H, Essayed WI, Cohen-Gadol A, Zada G, Schwartz TH: Resection of pituitary tumors: endoscopic versus microscopic. J Neurooncol 130:309-317, 2016

57. Stapleton CJ, Liu CY, Weiss MH: The role of stereotactic radiosurgery in the multimodal management of growth hormone-secreting pituitary adenomas. Neurosurg Focus 29(4):E11, 2010

58. Starke RM, Raper DM, Payne SC, Vance ML, Oldfield EH, Jane JA Jr: Endoscopic vs microsurgical transsphenoidal surgery for acromegaly: outcomes in a concurrent series of patients using modern criteria for remission. J Clin Endocrinol Metab 98:3190-3198, 2013
59. Tabaee A, Placantonakis DG, Schwartz TH, Anand VK: Intrathecal fluorescein in endoscopic skull base surgery. Otolaryngol Head Neck Surg 137:316-320, 2007

60. van Bunderen CC, van Varsseveld NC, Baayen JC, van Furth WR, Aliaga ES, Hazewinkel MJ, et al: Predictors of endoscopic transsphenoidal surgery outcome in acromegaly: patient and tumor characteristics evaluated by magnetic resonance imaging. Pituitary 16:158-167, 2013

61. Wagenmakers MA, Netea-Maier RT, van Lindert EJ, Pieters GF, Grotenhuis AJ, Hermus AR: Results of endoscopic transsphenoidal pituitary surgery in 40 patients with a growth hormone-secreting macroadenoma. Acta Neurochir (Wien) 153:1391-1399, 2011

62. Wang YY, Higham C, Kearney T, Davis JR, Trainer P, Gnanalingham KK: Acromegaly surgery in Manchester revisited-the impact of reducing surgeon numbers and the 2010 consensus guidelines for disease remission. Clin Endocrinol (Oxf) 76:399-406, 2012

63. Wilson TJ, McKean EL, Barkan AL, Chandler WF, Sullivan SE: Repeat endoscopic transsphenoidal surgery for acromegaly: remission and complications. Pituitary 16:459-464, 2013

64. Yamada S, Fukuhara N, Oyama K, Takeshita A, Takeuchi Y: Repeat transsphenoidal surgery for the treatment of remaining or recurring pituitary tumors in acromegaly. Neurosurgery 67:949-956, 2010

65. Yang I, Kim W, De Salles A, Bergsneider M: A systematic analysis of disease control in acromegaly treated with radiosurgery. Neurosurg Focus 29(4):E13, 2010

66. Yildirim AE, Sahinoglu M, Divanlioglu D, Alagoz F, Gurcay AG, Daglioglu E, et al: Endoscopic endonasal transsphenoidal treatment for acromegaly: 2010 consensus criteria for remission and predictors of outcomes. Turk Neurosurg 24:906-912, 2014

\section{Disclosures}

Dr. Schwartz reports holding stock options in Visionsense.

\section{Author Contributions}

Conception and design: Schwartz, Almeida. Acquisition of data: Almeida, Ruiz-Treviño, Liang, Chen, Shetty. Analysis and interpretation of data: Schwartz, Almeida, Liang, Omay, Chen, Shetty. Drafting the article: Almeida, Ruiz-Treviño, Omay. Critically revising the article: Schwartz, Omay, Shetty, Anand. Reviewed submitted version of manuscript: Almeida. Statistical analysis: Almeida, Ruiz-Treviño, Grover, Christos. Study supervision: Schwartz, Anand, Christos.

\section{Correspondence}

Theodore H. Schwartz, Department of Neurosurgery, Weill Cornell Medical College, NewYork-Presbyterian Hospital, 525 East 68th St., Box \#99, New York, NY 10065. email: schwarh@med. cornell.edu. 